France and the British Isles. Meanwhile, from the south-east or east, there came into Europe the knowledge of iron.

The Early Iron Age that followed is the dawn of European history. The culture with which these great movements led it to open is round the Egean called the Geometric, in Italy the Villanovan and Etruscan, and northwards of these the Hallstatt culture, from the great cemetery site in Upper Austria where it was first recognised, and where the Duchess of Mecklenburg in her turn came to excavate. East of the central Alps, the peoples of the Hallstatt culture were predominantly Illyrians. These Illyrians lay open to the east whence were coming the Scyths, they stretched down the Balkan Peninsula to the confines of Greece, they marched beyond the head of the Adriatic with Villanovan and Etruscan Italy, and to the north-west they mingled with the future Celts.

Carniola, where the routes from Greece and Italy meet, with the ways east and north and west lying open behind, is the key to the whole great nexus. Here, in cemetery after cemetery of surpassing richness, we can trace the development and appraise the character of the Hallstatt civilisation as never before, in the Duchess's great collection. It would be impossible to go into details here: the total number of excavated graves is estimated at more than 1,300 , and a reckoning of 20,000 individual objects may be short of the truth. But if this mass of material, scientifically interpreted, helps us to understand the Hallstatt civilisation at its focal point, it opens our eyes to the unity of a great stretch of human history. For, linked as it was to Etruscan Italy and Geometric Greece, with the shadow of the old Mycenæan Empire behind them, the Hallstatt civilisation was spread out over barbarian Europe, to give birth to that of the Celts whose conquests in east and west made way for the Roman Empire, and to last on meanwhile in Carniola, and more strongly still in the lands to south-eastward, until it passed under that Empire itself. Standing here now, we can at once salute the spirit of Augustus and invoke the ghost of Agamemnon.

\title{
Obituary
}

Prof. J. Cossar Ewart, F.R.S.

$\mathrm{T}$ HE death of Prof. James Cossar Ewart removes one who worked with distinction for more than half a century in the field of zoology and was a pioneer in the study of hybridisation and other problems of animal breeding.

Prof. Ewart was born at Penycuik, Midlothian, in 1851 and in 1871 entered the University of Edinburgh as a medical student. After graduating in 1874 he acted for six months as demonstrator of anatomy under Turner and was then appointed curator of the Zoological Museum in University College, London. Besides adding numerous preparations both of vertebrates and invertebrates to the collection, he assisted Lankester, who had been appointed professor in University College in 1874, to organise the first course of practical zoology in the College, and in the absence of his chief in the summer of 1878 he was in charge of this class. During this period Ewart published papers on the structure of the lens and retina, on points in the anatomy of the lamprey and on the life-history of lower organisms, including Bacillus anthracis, and for this last work, presented as a thesis for the degree of M.D. (Edin.), he was awarded a gold medal.

At the end of the summer term of 1878 Ewart returned to Edinburgh and became a lecturer in anatomy in the extra-mural School of Medicine, but after about two months in this office he was appointed professor of natural history in the University of Aberdeen and began his work there in January 1879. In the same year he established a small marine zoological station near Aberdeen-the first marine laboratory in Britain -in which he and others conducted investigations during the next three years. The most notable product of the station was the material for the
Croonian lecture of 1881, by Ewart and Romanes, on the locomotor system of echinoderms.

After three active years in Aberdeen, Ewart was appointed, in succession to Wyville Thomson, to the chair of natural history in Edinburgh, which he held for forty-five years-1882-1927. He reorganised the class of practical zoology, hitherto optional and attended by only a small proportion of the students, and established a more advanced practical course for students who were specially interested in zoology. He further developed the teaching and research in his Department by the institution of lectureships in embryology (in 1885, held first by George Brook and afterwards for twenty-six years by John Beard), in invertebrate zoology (1901) and in heredity and genetics (1910, to which Arthur Darbishire was appointed).

In 1882 Ewart became scientific member of the Fishery Board for Scotland, and during the next seven years was the author or joint author of about a dozen papers and reports on fisheries subjects including the natural history of the herring. Then followed the series of well-known papers, from 1888 until 1895 , on the electric organ of the skate (Raia) and on the cranial nerves and lateral sense organs of this fish and Lamargus. $\mathrm{He}$ showed that the electric organ of the skate, discovered by Dr. James Stark of Edinburgh in 1844, was a developing and not a degenerating structure, and that in its most primitive condition, as seen in Raia radiata, the muscle fibres from which the electric elements are formed are less modified than in other species, and that in Raia batis the modification has proceeded so far that the adult electric organ presents little trace of its relation to muscular tissue.

Ewart's investigations on the cranial nerves were undertaken at a time of considerable activity in 
neurological research and "trusting mainly to the old methods of the comparative anatomist" he gave an accurate account of the lateral sense organs and their nerve supply and of the macroscopic anatomy of the cranial nerves of Lomargus and, with J. C. Mitchell, of Raia. He had further preparations made for continuing his work on the cranial nerves, but was diverted by his interests in the development of the limbs of the horse. He showed in 1894 that in foetal horses a digit com. posed of three phalanges was borne on the distal end of each of the splint bones which represent the metacarpals and metatarsals of the second and fourth digits, but that about the time of birth the phalangeal joints disappear, the phalanges become ossified and, early in the second year, fuse with their respective splints forming the "buttons". This was an important and interesting contribution in view of the reduction of these digits known to have occurred in the evolution of the limbs of the horse.

About 1895 Ewart began his work in animal breeding. It is to be remembered that Mendel's laws were not rediscovered until 1900, but Ewart devised careful experiments to throw light on some of the problems of cross breeding and inbreeding, on reversion and on telegony. The best known of these investigations were those in which mares of various breeds were crossed with a Burchell's zebra stallion. Ewart thoroughly studied the hybrids and presented the results, together with those of many other breeding experiments in a volume, "The Penycuik Experiments" (1899), which attracted much attention. The zebra hybrids formed an interesting exhibit at the Royal Agricultural Society's Show in York in 1900. His investigations to test the theory of telegony - that a sire may 'infect' the dam served by him and leave his mark on her subsequent offspring by other sires-led him to a negative result, and he showed that the appearances described could be explained as examples of reversion.

Several papers followed on different subspecies of horses, and on the origin and evolution of horses and ponies, and Ewart described (1906) the animal remains, more particularly of a considerable number of horses, found in the Roman fort at Newstead near Melrose. Papers on domestic sheep and their wild ancestors marked a further development of Ewart's work, and the renting from 1913 until 1921 by the University of Edinburgh of a farm at Fairslacks enabled him to conduct investigations for the improvement of the fleece of sheep, which brought him into contact with the woollen industry in Scotland; he also became an active member of the Council of the Wool Industries Research Association in Leeds. Ewart's expert knowledge was the chief factor which decided the Board of Agriculture for Scotland to constitute in Edinburgh in 1913 a committee on animal breeding. This committee was suspended during the War but was re-established in 1919 and in 1920 appointed Dr. (now Prof.) F. A. E. Crew as director of research, under whom the work in genetics and animal breeding has developed into a separate Department of the University.

The rearing of penguins in the Zoological Park in Edinburgh afforded Ewart the opportunity to study the sequence and the structure of the different types of feathers. In a paper in 1921 he discussed the origin and history of feathers, and he continued until about two years ago to devote attention to the relationship of feathers and scales.

Ewart had skilful hands and could make a good dissection and admirable drawings; early examples of his drawings are to be found in the plates of Turner's lectures on the placenta (1876). He was elected F.R.S. in 1893, was awarded the Neill Medal and Prize of the Royal Society of Edinburgh in 1898 in recognition of his investigations on telegony, and in 1928 received the honorary degree of LL.D. from his old University. He retired from his chair in 1927 and died in Penycuik on December 31, 1933. He is survived by his widow, a married daughter and a son, who is a surgeon in London.

J. H. A.

\section{DR. F. H. H. GUILlemard}

Francis Henry Hild Guim, gmard, whose death occurred on December 23, was born at Eltham in 1852. Travel and natural history made a strong appeal to him from boyhood onwards. At an early age he announced his intention of becoming a traveller and a doctor, and his first published work was an article on "Pigeons" in the Boys' Weekly in 1866. Destined for Rugby, he was kept at home between 1866 and 1868 owing to ill-health and afterwards went to a. 'crammer' at Richmond. By this time he had become an habitué of Stevens' rooms in King Street, Covent Garden, never missing a natural history sale if he could help it and seeing there the great ornithologists of the day-Newton, Lilford, Howard Saunders and others. In 1870 he went up to Gonville and Caius College, Cam. bridge, where he read medicine under Humphry and Paget.

As an undergraduate, Guillemard made two journeys to the Orkneys, chiefly for bird study, which was one of the ruling passions of his life, and immediately after he had taken his degree he made a more ambitious trip to Lapland. At St. Bartholomew's Hospital he was clinical clerk to Patrick Black at the time when Robert Bridges was house physician.

Taking his M.B. degree in 1876, Guillemard entertained no thoughts of medical practice. Travel was his objective, and in 1877 he had the opportunity of exploring some little-known parts of Africa, trekking across the Transvaal and the Orange Free State in the old bullock-wagon manner and visiting the diamond fields in their early days. His articles on the ornithology of South Africa were published in the Field in 1880 and 1881, and the journey also provided the subject for his M.D. thesis, "On the Endemic 